\title{
Processes and technologies for the recycling and recovery of spent lithium-ion batteries
}

\author{
J. Ordoñez ${ }^{\mathrm{a}}$, E.J. Gago ${ }^{\mathrm{a}, *}$, A. Girard ${ }^{\mathrm{b}}$ \\ ${ }^{a}$ School of Civil Engineering, University of Granada, Granada, Spain \\ ${ }^{\mathrm{b}}$ Faculty of Engineering and Sciences, Adolfo Ibáñez University, Viña del Mar, Chile
}

\begin{abstract}
LiBs pose a very specific threat, given that they contain a high percentage of dangerous heavy metals. From the $4000 \mathrm{t}$ of used lithium-ion batteries collected in 2005, $1100 \mathrm{t}$ of heavy metals and more than $200 t$ of toxic electrolytes were generated. This is why a lot of attention has been paid to the development of the technology necessary to recover and recycle LiBs in order not only to protect the environment but also to conserve resources. The recovery of major spent cell components is beneficial both in terms of environmental protection and also for the provision of raw materials. The authors of this article carried out a state of the art on the technologies used in the recycling and regeneration of industrial lithium-ion batteries. The main objective of such technologies is to enable the recycling of valuable elements present in the batteries, such as cobalt, nickel and copper, in a way which is both profitable and environmentally friendly. All the technologies used in the manufacture of lithium-ion batteries are constantly changing makes subsequent changes to the research into recycling and recovery technologies necessary. This does not mean merely finding ways to recover the precious metals, but also to recover other materials which may harm the environment, in order to dispose of them appropriately. The discussion of this research clearly reflects that:
\end{abstract}

- There are very few studies on the recovery of metals such as graphite, the electrolyte in spent LIBs, and it is our belief that more research is needed in this area.

- The research into the application of microorganisms in the used lithium batteries is few and far between.

- It is important to find ways to recover the precious metals and to recover other materials which may harm the environment, in order to dispose of them appropriately.

\footnotetext{
* Corresponding author. Tel.: +34958 2413 51; fax: +34958 242715 .

E-mail address: ejadraque@ugr.es (J. Ordoñez).
} 


\section{Introduction}

The purpose of this paper is to review the current status of the recycling and recovering technologies of spent lithium-ion batteries. It introduces the structure and components of the lithiumion batteries and summarizes all kinds of recycling and recovery processes from spent lithium-ion. Also, the problems and prospects arising from the studies of their recycling technologies have been put forward.

Lithium batteries (LiBs) are generally composed of a cathode, an anode, an organic electrolyte and a separator. Lamination of the cathode, anode and separator, achieved through compression, makes electrical contact possible. The anode is a copper plate coated with a mixture of graphite, a conductor, binder polyvinylidene fluoride (PVDF) and additives such as $\mathrm{LiPF}_{6}$ [1].

Similarly, the cathode is an aluminum plate coated with a mixture of active cathode material, an electric conductor, a PVDF binder, and additives. $\mathrm{LiCoO}_{2}$ is commonly used as the active cathode material for almost all LiBs on the market [1]. Reference names for Li-ion batteries are shown in Table 1.

Advantages of LiBs such as their lightweight components, inflated energy capacity, high voltage per cell, favorable discharge resistance, ability to work through a large number of regeneration cycles, and a wide range of temperatures, alongside the fact that they are less harmful to the environment than other batteries, have meant that, since their introduction onto the market in 1991 [3], LiBs have been widely used in mobile electronic applications like PCs, video cameras, and mobile telephones, and later as energy storing devices in electric vehicles and stationary storage of renewable energies such a solar and wind. The success of lithium ion technology for the latter applications will depend largely on the cost, safety, cycle life, energy, and power, which are in turn controlled by the component materials used. Accordingly, several authors provide reviews focusing on the challenges and prospects associated with the electrode materials [4-7].

Table 2 provides an overview of the major class of lithium insertion electrode materials. Each system in Table 2 has its own advantages and disadvantages, which often dictate their application areas.

Global consumption of LiBs between the years 2000 and 2004 stood at around 500-700 million cells, whilst, according to the
International Telecommunications Union (ITU), the number of mobile telephone users exceeded 6.8 billion in 2013 .

LiBs pose a very specific threat, given that they contain a high percentage of dangerous heavy metals. From the $4000 \mathrm{t}$ of used lithium-ion batteries collected in 2005, $1100 \mathrm{t}$ of heavy metals and more than $200 \mathrm{t}$ of toxic electrolytes were generated $[8,9,40]$.

Some of the components of these batteries are difficult to break down; meaning that discarding them after their end-of-life into municipal waste landfill sights may pollute the soil and underground water, while their incineration contaminates the air by releasing toxic gases [10].

Dorella and Mansur [11] ascertained the metal content of LiBs and found that valuable metals such as aluminum, cobalt, lead and lithium were the main components to be separated. They emphasized that irresponsible disposal of spent LiBs will result in environmental pollution.

This is why a lot of attention has been paid to the development of the technology necessary to recover and recycle LiBs in order not only to protect the environment but also to conserve resources. The recovery of major spent cell components is beneficial both in terms of environmental protection and also for the provision of raw materials [12-16].

\section{Selection of research studies}

This paper systematically reviews recent research on technologies used in the recycling and regeneration of industrial lithiumion batteries. The main objective of such technologies is to enable the recycling of valuable elements present in the batteries, such as cobalt, nickel and copper, in a way which is both profitable and environmentally friendly. According to Dewulf et al. [17], the use of recycled cobalt and nickel in the production of the active cathode material present in LiBs leads to the following savings: $51.3 \%$ in natural resources, $45.3 \%$ in fossil fuels, and $57.2 \%$ in nuclear energy demand.

The methodology used for this systematic review is described in $[18,19]$, and consists of the following steps:

Table 1

Reference names for Li-ion batteries [2].

\begin{tabular}{|c|c|c|c|}
\hline Chemical name & Material & Short form & Characteristics \\
\hline Lithium Cobalt Oxide ${ }^{a}$ & $\mathrm{LiCoO}_{2}(60 \% \mathrm{Co})$ & Li-cobalt & Its high capacity makes it ideal for mobile phones, laptops and cameras. \\
\hline Lithium Manganese Oxide $^{a}$ & $\mathrm{LiMn}_{2} \mathrm{O}_{4}$ & $\begin{array}{l}\text { Li-manganese, or } \\
\text { spinel }\end{array}$ & $\begin{array}{l}\text { This is the safest kind of battery, with a lower capacity than Li-cobalt but a high } \\
\text { specific power and long life. Used in power tools, e-bikes. EV, medical, hobbyist. }\end{array}$ \\
\hline Lithium Iron Phosphate $^{a}$ & $\mathrm{LiFePO}_{4}$ & Li-phosphate & \\
\hline $\begin{array}{l}\text { Lithium Nickel Manganese } \\
\text { Cobalt Oxide }\end{array}$ & $\begin{array}{l}\mathrm{LiNiMnCoO}_{2}(10-20 \% \\
\text { Co) }\end{array}$ & NMC & \\
\hline $\begin{array}{l}\text { Lithium Nickel Cobalt Alumi- } \\
\text { num Oxide }\end{array}$ & $\mathrm{LiNiCoAlO}_{2}(9 \% \mathrm{Co})$ & NCA & \\
\hline Lithium Titanate $^{\mathrm{b}}$ & $\mathrm{Li}_{4} \mathrm{Ti}_{5} \mathrm{O}_{12}$ & Li-titanate & Gaining importance in electric powertrain and grid storage. \\
\hline
\end{tabular}

\footnotetext{
a Cathode material.

${ }^{\mathrm{b}}$ Anode material.
} 
Table 2

Advantages and disadvantages of the electrode materials [4].

\begin{tabular}{|c|c|c|c|c|c|}
\hline Electrode material & $\begin{array}{l}\text { Cell voltage } \\
\text { (V) }\end{array}$ & $\begin{array}{l}\text { Capacity } \\
(\mathrm{mAh} / \mathrm{g})\end{array}$ & $\begin{array}{l}\text { Specific energy } \\
(\mathrm{mWh} / \mathrm{g})\end{array}$ & Advantages & Disadvantages \\
\hline $\begin{array}{l}\text { Layered } \mathrm{LiCoO}_{2} \text { cathode } \\
\text { (2-d structure) }\end{array}$ & $\sim 4$ & 140 & 560 & $\begin{array}{l}\text { High electronic and } \mathrm{Li}^{+} \text {ion conductivity; } \\
\text { Revolutionized the portable electronics } \\
\text { market }\end{array}$ & $\begin{array}{l}\text { Expensive and toxic Co; safety concerns; } \\
\text { only } 50 \% \text { of the theoretical capacity can be } \\
\text { utilized }\end{array}$ \\
\hline $\begin{array}{l}\text { Spinel } \mathrm{LiMn}_{2} \mathrm{O}_{4} \text { cathode } \\
\text { (3-d structure) }\end{array}$ & $\sim 4$ & 120 & 480 & $\begin{array}{l}\text { Inexpensive and environmentally } \\
\text { benign } \mathrm{Mn} \text {; high electronic and } \mathrm{Li}^{+} \text {ion } \\
\text { conductivity; excellent rate capability; good } \\
\text { safety }\end{array}$ & $\begin{array}{l}\text { Severe capacity fade at elevated tempera- } \\
\text { tures }\left(55^{\circ} \mathrm{C}\right)\end{array}$ \\
\hline $\begin{array}{l}\text { Olivine } \mathrm{LiFePO}_{4} \text { cathode } \\
\quad \text { (1-d structure) }\end{array}$ & $\sim 3.5$ & 160 & 560 & $\begin{array}{l}\text { Inexpensive and environmentally benign Fe; } \\
\text { covalently bonded } \mathrm{PO}_{4} \text { groups lead to excellent } \\
\text { safety }\end{array}$ & $\begin{array}{l}\text { Low electronic and } \mathrm{Li}^{+} \text {ion } \\
\text { conductivity; needs small } \\
\text { particle size and carbon } \\
\text { coating to realize high rate } \\
\text { capability; high processing cost }\end{array}$ \\
\hline Graphite anode & $\sim 0.1$ & 370 & - & $\begin{array}{l}\text { Inexpensive and environmentally benign } C \text {; } \\
\text { low operating potential maximizes cell voltage }\end{array}$ & $\begin{array}{l}\text { Solid-electrolyte interfacial layer forma- } \\
\text { tion and lithium } \\
\text { plating lead to safety concerns; high pro- } \\
\text { cessing cost }\end{array}$ \\
\hline
\end{tabular}

- An exhaustive literature search performed by applying predefined criteria for the identification of the most relevant articles in the field.

- A critical evaluation of the quality of the selected articles achieved by synthesizing their content and summarizing the results and conclusions.

For this research, the data were obtained by searching databases of different disciplines (e.g. power sources, electric and hybrid electric vehicles, renewable energy, energy conversion...). The search engines used were those on the Internet, on environmental and battery web pages. The key words for the searches were battery, battery and lithium, recycling and recovering. The inclusion criteria for articles were explicitly defined according to the characteristics of the study. Any article to be included in the review had to be an in-depth study of the battery, its characteristics, recycling and regeneration technologies, effects on the environment, etc.

The structure of this review reflects the inventory of recycling and regeneration technologies to be applied to lithium-ion batteries. These technologies were identified by analyzing the contents of the articles, presupposing that there is a clear overlap between them because, on the one hand, in the recovery and recycling of lithium-ion batteries, the different processes and technologies used tend to overlap and, on the other, many of the results used are based on the implementation of various processes and/or technologies for recovery and recycling of batteries.

The articles analyzed in the review were retrieved from the following data bases: Journal Citation Reports, Web of Knowledge, Web of Science, and Scopus. From each article, the research objectives, description of methodology applied or developed, geographical location of the study, theoretical premises, computer tools used, and above all, information in the conclusions regarding technologies for the recycling and regeneration of lithium-ion batteries were extracted.

\section{Technologies for the recycling and regeneration of lithium- ion batteries}

Lithium-ion batteries are made up of heavy metals, organic chemical products, and plastics, in a proportion of $5-20 \%$ cobalt, 5-10\% nickel, 5-7\% lithium, 15\% organic chemical products and 7\% plastics. This composition may vary slightly depending on the manufacturer. When the waste generated by spent lithium-ion batteries is properly processed, the heavy metals such as cobalt or lithium can be recovered. The recovery of these metals is also very important and desirable for the conservation and the defense of the environment.

In recent years, countries have strengthened legislation regarding more flexible recycling processes, intended to ensure the availability of accessible collection points that allow end users to dispose of their spent batteries at no cost. For example, the EU requires each Member State to reach a minimum collection rate in 2015 of between $15-25 \%$ of spent batteries and accumulators with a recycling efficiency of at least $45-50 \%$ [10].

Existing methods of recycling and regeneration for LiBs comprise principally physical and chemical processes. Among the physical processes are:

- Mechanical separation processes

- Thermal treatment

- Mechanochemical processes

- Dissolution processes

The chemical processes include:

- Acid leaching

- Bioleaching

- Solvent extraction

- Chemical precipitation

- Electrochemical processes

It is worth noting that, as mentioned above, there is a clear overlap between the different processes and technologies applied, given their close correlation and also due to the fact that the results presented are based on the application of various processes and/or technologies for the recovery and recycling of batteries. Thus, Castillo et al. [36], propose the use of nitric acid for the leaching of the lithium. During their proposed process they also include a chemical treatment of the filtrate and a thermal treatment of the solid residue. Lee and Rhee [38] applied a recycling process which involves mechanical and hydrometallurgical treatment, as well as an amorphous citrate precursor process (ACP) to prepare $\mathrm{LiCoO}_{2}$ from spent LiBs.

\subsection{Physical processes}

Among the physical processes for the recycling of spent LiBs, the function of the mechanical separation processes or techniques is to separate materials according to different properties such as density, conductivity, magnetism, etc. [20]. The thermal processes 
are generally associated with the production of steel, ferro alloys or other metal alloys. The mechanochemical process uses a grinding technique which turns the crystallized structure of $\mathrm{LiCoO}_{2}$ (the positive electrode present in LiBs) into a disordered system, allowing easy extraction of useful substances such as Co and Li through acid leaching at room temperature using the scrap waste gained from LiBs. The dissolution process involves using specific organic reactors to dissolve the adhesive substance (polyvinylidene fluoride), which joins the anode and cathode electrodes. This process makes $\mathrm{LiCoO}_{2}$ easily separable from its support substrate and allows for effective recovery.

\subsubsection{Mechanical separation processes}

Unlike other batteries, lithium-ion batteries often explode during the recycling process through radical oxidation when lithium metal produced from battery overcharge sustains a mechanical shock on exposure to air. Therefore, a preliminary mechanical separation, carried out before the heavy metals which make up the lithium-ion batteries are recovered, is necessary. Mechanical separation is also advantageous as it reduces the volume of waste and separates and enriches the components of the batteries [21].

Mechanical separation processes are usually applied as a pretreatment. Their function is to treat the outer cases and shells and to concentrate the metallic fraction, which will lead to a hydrometallurgical or a pyrometallurgical recycling process [22,39].

Shin et al. [23] propose a new procedure for the recovery of metals in spent lithium-ion batteries. It includes mechanical separation of the particles of oxide, cobalt and lithium and a hydrometallurgical process for the recovery of the lithium and the cobalt. The experimental results seem to indicate that a concentration of $15 \mathrm{vol} \%$ of hydrogen peroxide in sulfuric acid leaching is sufficient for total recovery of the lithium and cobalt through fast leaching.

Li et al. [40] applied a hydrometallurgical process based on leaching to recover cobalt and lithium from spent lithium-ion batteries (LiBs). The proposed procedure includes the mechanical separation of particles containing metal.

The disadvantage of applying mechanical separation processes is that not all the components of spent LiBs are completely separated since they are composed of several metals alongside organic and inorganic substances which penetrate into each other, whilst their small volume and accurate, fine, complicated structure make components difficult to separate [12].

Bertoul et al. [24], apply mechanical methods (grinding, sieving and elutriation) to separate the different materials that compose LIBs. Through the mechanical processing, it was possible to separate the following materials: $17.2 \mathrm{wt} \%$ of $\mathrm{Cu} / \mathrm{Al}, 15.8 \mathrm{wt} \%$ of $\mathrm{Al}$ (external casing); $42.7 \mathrm{wt} \%$ of $\mathrm{LiCoO}_{2}$ and graphite, $6.1 \mathrm{wt} \%$ of polymers and $2.3 \mathrm{wt} \%$ of a mixture that can be reprocessed.

\subsubsection{Thermal treatment}

Thermal processes usually consist of furnace heating in a controlled atmosphere to between $100-150{ }^{\circ} \mathrm{C}$ to separate out the insoluble organic additives and adhesives. This process is also used as an intermediary step after each bout of hot acid leaching. Heating time is not standardized but never exceeds two hours [12].

Bahgat et al. [25] successfully synthesized a microcrystalline Li/ Co ferrite composite of about $0.14 \mu \mathrm{m}$ crystallite size by treating a mixture of cathode material of spent lithium-ion batteries and iron oxide at temperatures $\geq 1000^{\circ} \mathrm{C}$ and for $\geq 4 \mathrm{~h}$ firing times.

Castillo et al. [36], propose the use of nitric acid for the leaching of lithium. This process also includes thermal treatment of the solid residue. The solid residue (made up of iron, cobalt nickel hydroxide mixture and some traces of $\left.\mathrm{Mn}(\mathrm{OH})_{3}\right)$ is introduced in a muffle furnace at $500{ }^{\circ} \mathrm{C}$ for $2 \mathrm{~h}$ in order to eliminate the carbon and the organic compounds.

Lee and Rhee [38], apply a recycling process using mechanical, thermal, hydrometallurgical and sol-gel steps to recover the cobalt and the lithium from the spent lithium batteries and to synthesize $\mathrm{LiCoO}_{2}$ from leach liquor as cathode active materials.

Thermal treatment is advantageous in so far as the operations necessary are simple and convenient. However the process has been linked to high emissions of dioxins, chloride compounds and mercury, making it necessary to install special equipment to purify the gases and smoke caused by combustion.

\subsubsection{Mechanochemical process}

The common mechanochemical process is a special grinding technique for $\mathrm{LiCoO}_{2}$ chemistries. It consists of exposing greater surface areas enabling a successful acid leaching for the recovery of cobalt and lithium. The dissolution process uses organic reactants to dissolve the adhesive substance, generally polyvinylidene fluoride (PVDF).

Zhang et al. [26] carried out extractions of valuable substances from scrap $\mathrm{LiCO}_{0.2} \mathrm{Ni}_{0.8} \mathrm{O}_{2}$ metals containing polyvinylidene fluoride (PVDF) at room temperature by applying a $1 \mathrm{~N} \mathrm{HNO}_{3}$ solution after mechanochemical (MC) treatment had been executed using a planetary mill with and without $\mathrm{Al}_{2} \mathrm{O}_{3}$ powder. The results showed that using $\mathrm{Al}_{2} \mathrm{O}_{3}$ for mechanochemical treatment is very effective, enabling extraction of $\mathrm{Co}$ as well as $\mathrm{Ni}$ and $\mathrm{Li}$ at a high yield of more than $90 \%$ from the amorphous scrap sample.

Tanaka el al. [27] propose a mechanochemical method to synthesize spinel $\mathrm{Li}_{4} \mathrm{Mn}_{5} \mathrm{O}_{12}$. This method involves grinding a mixture of $\mathrm{LiOH} \cdot \mathrm{H}_{2} \mathrm{O}$ and $\gamma-\mathrm{MnO}_{2}$ with a planetary ball mill, followed by thermal treatment, heating the substance to between 400 and $600{ }^{\circ} \mathrm{C}$, causing the mixture to crystallize in magnesium oxide and lithium. The spinel structure type of compound synthesized by applying this method consists of agglomerates with fine cubic grains of about $100 \mathrm{~nm}$.

Saeki et al. [28], developed a procedure to recover Co and $\mathrm{Li}$ from lithium-ion secondary (LIS) battery waste using the mechanochemical process. The process consists of co-grinding $\mathrm{LiCoO}_{2}$ with PVC in air to form $\mathrm{Li}$ and Co-chlorides. The ground product is subsequently leached with water to extract Co and Li. During the grinding phase, a mechanochemical reaction which occurs between the $\mathrm{LiCoO}_{2}$ and the PVC leads to the formation of chlorides which are soluble in water. According to these authors, the grinding phase is very important as it improves efficiency. Furthermore, the role of the PVC is important insofar as it provides a source of chlorides to be used during the mechanochemical process. For a proper, safe treatment of waste generated by PVC, Zhang et al. [29] and Saeki et al. [30] have developed a procedure which proposes the use of a grinding technique followed by leaching with water to dechlorinate the PVC.

Zhang and Saito [31] and Lee et al. [32], applied a mechanochemical process to extract useful substances from the lithiumion secondary battery scrap waste. The method consists of a grinding technique which turns the crystal structure of the $\mathrm{LiCoO}_{2}$ into a disordered system, allowing easy extraction of $\mathrm{Co}$ and $\mathrm{Li}$ through acid leaching at room temperature.

\subsubsection{Dissolution process}

The dissolution process offers a greater efficiency in the recovery of valuable components of spent batteries. The process weakens the adhesion of the PVDF which holds the electrode active materials (anode and cathode) to the current collectors. Therefore selecting the correct organic solvent able to dissolve either the polyvinylidene fluoride (PVDF) or the polytetrafluoroethylene (PTFE) is very important for a successful dissolution process. Among those solvents which have been successful at this stage are: $\mathrm{N}$ 
$\mathrm{N}$-dimethylformamide (DMF), N, N-dimethylacetamide (DMAC), Nmethylpyrrolidone (NMP) and dimethyl sulfoxide (DMSO) [16].

Contestabile et al. [21], offer a recycling process for lithium batteries carried out under laboratory conditions without the separation of the anode and cathode electrodes. The batteries were treated with $\mathrm{N}$-methylpyrrolidone (NMP) at $100{ }^{\circ} \mathrm{C}$ for one hour. The $\mathrm{LiCoO}_{2}$ was separated and recovered efficiently. The authors therefore demonstrated that the recovery of $\mathrm{LiCoO}_{2}$ is highly influenced by the adhesive agent used and by the rolling method of electrodes. However this process is impractical on an industrial scale, given the cost of the solvent used (NMP) to dissolve the polyvinylidene fluoride (PVDF).

Among all organic solvents tested, the use of DMSO at $60^{\circ} \mathrm{C}$ for 85 min may be the most efficient due to its low cost, zero toxicity and environmental safety [33].

Bankole and Lei [34] extracted the electrolyte solution into organic solvents such as ethanol or isobutyl alcohol water after manually or mechanically dismantling LiBs, leading to a reduction in the environmental pollution caused by the hydrolysis of electrolyte salt, $\mathrm{LiPF}_{6}$ and also the toxic electrolyte mixture. Interestingly, innovative conversion of $\mathrm{LiPF}_{6}$ to a useful compound such as $\mathrm{Li}_{2} \mathrm{SiF}_{6}$ was achieved for the first time.

\subsection{Chemical processes}

The chemical processes are mainly hydrometallurgical methods involving acid or base leaching, solvent extraction, chemical precipitation, bioprocess and electrochemical process or a combination of these processes.

\subsubsection{Acid leaching}

Leaching is a process during which one or more solutes are extracted from a solid through the application of a liquid solvent. Both phases come into close contact and the solute or solutes employed can diffuse from the solid to the liquid phase, leading to a separation of the original components of the solid.

The lithium cobalt oxide $\left(\mathrm{LiCoO}_{2}\right)$ used as an active cathode is not easily dissolved using common chemical leaching products. The leaching of $\mathrm{LiCoO}_{2}$ from spent LiBs is usually carried out using inorganic acids such as $\mathrm{H}_{2} \mathrm{SO}_{4}$ [35], $\mathrm{HCl}[21]$ and $\mathrm{HNO}_{3}[36,38]$ as leaching agents. Zhang et al. [3] performed a study of various leachates to leach the lithium cobalt oxide such as sulfurous acid, hydroxylamine hydrochloride and hydrochloric acid. Hydrochloric acid gave the best performance among the three leachates examined. A leaching efficiency of more than $99 \%$ of cobalt and lithium could be achieved when $4 \mathrm{M} \mathrm{HCI}$ solution was used at a temperature of $80^{\circ} \mathrm{C}$ and a reaction time of $1 \mathrm{~h}$. Subsequently, hydrochloric acid was applied for the leaching of lithium and cobalt by other researchers such as Contestabile et al. [21]. Castillo et al. [36] used nitric acid instead of chlorhydric acid in the lithium leaching processes. A new procedure for the nitric acid leaching of lithium and cobalt from lithium-ion batteries was proposed by Lee and Rhee [37], and the procedure was extended to regenerate lithium cobalt oxide electrodes from the leachate and to examine the performance of the electrode [38].

Kim et al. [39] propose a leaching process using sulfuric acid to recover lithium and cobalt. The effects of the leaching agent, particle size and incineration during acid leaching were investigated in order to find the optimum condition for metal recovery. The procedure includes the mechanical separation of lithium cobalt oxide particles, which can be applicable in the commercial recycling of lithium-ion battery waste.

$\mathrm{Li}$ et al. [40] used citric acid and hydrogen peroxide $\left(\mathrm{C}_{6} \mathrm{H}_{8} \mathrm{O}_{7} \cdot \mathrm{H}_{2} \mathrm{O}\right.$ and $\mathrm{H}_{2} \mathrm{O}_{2}$ ) to investigate reaction conditions. $\mathrm{Co}$ and $\mathrm{Li}$ were recovered from the leaching solutions as their respective citrates. Conditions for a recovery of more than $90 \%$ Co and nearly $100 \% \mathrm{Li}$ were achieved experimentally by varying the concentrations of leachate, time and temperature of the reaction as well as the starting solid-to-liquid ratio.

Nayl et al. [41], established a procedure to dissolve and recover $\mathrm{Al}, \mathrm{Cu}, \mathrm{Mn}, \mathrm{Co}, \mathrm{Ni}$ and $\mathrm{Li}$ present in the powder made as a result of mixing and grinding different spent lithium-ion batteries. Here, $98.8 \%$ of $\mathrm{Li}$ was leached from the alkali residue of spent LiBs using $2.0 \mathrm{M} \mathrm{H}_{2} \mathrm{SO}_{4}$ with $4.0 \% \mathrm{H}_{2} \mathrm{O}_{2}$ for 120 min with an $\mathrm{L} / \mathrm{S}$ mass ratio of $10 / 1$ at $70^{\circ} \mathrm{C}$.

Zou et al. [42], developed a methodology to recycle mixed cathode materials including $\mathrm{LiCoO}_{2}, \mathrm{LiMn}_{2} \mathrm{O}_{4}, \mathrm{LiNi}_{0.33} \mathrm{Mn}_{0.33} \mathrm{Co}_{0.33} \mathrm{O}_{2}$, and $\mathrm{LiFePO}_{4}$. A method is adopted to separate $\mathrm{Fe}$ from $\mathrm{Ni}$, Co and $\mathrm{Mn}$ in solution. The mixture of $\mathrm{Ni}(\mathrm{OH})_{2}, \mathrm{Co}(\mathrm{OH})_{2}$, and $\mathrm{Mn}(\mathrm{OH})_{2}$ with recovered $\mathrm{Li}_{2} \mathrm{CO}_{3}$ is used to synthesize $\mathrm{LiNi}_{0.33} \mathrm{Mn}_{0.33} \mathrm{Co}_{0.33} \mathrm{O}_{2}$. Analysis results show that almost $100 \%$ of $\mathrm{Ni}, \mathrm{Mn}$, Co are recovered, and experiments demonstrate that about $80 \% \mathrm{Li}$ are recycled in the form of $\mathrm{Li}_{2} \mathrm{CO}_{3}$.

Li et al. [43], tested three acids for the leaching process: two inorganic acids $\left(\mathrm{H}_{2} \mathrm{SO}_{4}\right.$ and $\left.\mathrm{HCl}\right)$ and one organic acid (citric acid, $\mathrm{C}_{6} \mathrm{H}_{8} \mathrm{O}_{7} \cdot \mathrm{H}_{2} \mathrm{O}$ ). The results show that the leaching of $\mathrm{Co}$ and $\mathrm{Li}$ is more efficient with citric acid than with the two inorganic acids. More than $96 \%$ Co and nearly $100 \%$ Li were recovered from spent LIBs. The optimal leaching conditions were $0.5 \mathrm{M}$ citric acid with $0.55 \mathrm{M} \mathrm{H}_{2} \mathrm{O}_{2}$, a solid-to-liquid ratio of $25 \mathrm{~g} \mathrm{~L}^{-1}$, a temperature of $60{ }^{\circ} \mathrm{C}$, leaching time of $5 \mathrm{~h}$, and ultrasonic power of $90 \mathrm{~W}$.

Zhang et al. [44], proved that compared with inorganic acids and alkalis, the acidic organic solvent could be reused in the subsequent separating and leaching steps. They applied a novel process in which an acidic organic solvent was employed to separate $\mathrm{LiNi}_{1 / 3} \mathrm{Co}_{1 / 3} \mathrm{Mn}_{1 / 3} \mathrm{O}_{2}$ cathode material and aluminum foil from spent lithium-ion batteries.

The leaching of lithium nickel cobalt aluminum oxide (NCA) cathodes has been investigated in sulfuric, nitric and hydrochloric acids. Joulie et al. [45] found the optimum leaching conditions, $4 \mathrm{~mol} \mathrm{~L}^{-1}$ hydrochloric acid, $90^{\circ} \mathrm{C}, 18 \mathrm{~h}$ with $5 \%(\mathrm{w} / \mathrm{v})$ solid to liquid ratio. Under these experimental conditions, all valuable metals of cathode material are leached out.

Zeng et al. [46], obtained results from theory and experiments showing that $\mathrm{LiCoO}_{2}$ can be leached using oxalic acid without an assistance from hydrogen peroxide solution. The recovery rate of lithium and cobalt from spent LIBs can reach about $98 \%$ and $97 \%$, respectively at $150 \mathrm{~min}$ retention time, $95{ }^{\circ} \mathrm{C}$ heating temperature, $15 \mathrm{~g} \mathrm{~L}^{-1}$ solid-liquid ratio, and $400 \mathrm{rpm}$ rotation rate.

\subsubsection{Bioleaching}

Bioleaching is a low-cost technique used in the treatment of conventional waste which is highly efficient and has few industrial requirements [47]. Bioleaching is a process of mineral bio-oxidation, assisted using microorganisms, which transforms insoluble metal sulfates into water-soluble metal sulfates [48].

Mishra et al. [49] used a bioleaching method for the extraction of cobalt and lithium from spent lithium-ion secondary batteries. Results revealed that a culture of ferrooxidans can produce sulfuric acid to leach metals indirectly from the LiBs. Cobalt was leached faster than lithium. The aim of the use of Fe (II) ion in the leaching experiments was to proliferate the cell growth in the lixiviant: the higher the Fe (II) ion concentration, the slower the metal dissolution. The $\mathrm{Fe}$ (III) ion formed during the investigation was found to be precipitated with the metals in the leach residues. Higher solid/liquid ratios prevented bacterial activity in the process as higher metal concentrations are considered to be toxic for cells.

Xin et al. [50] investigated the mechanism of bioleaching Co and Li from spent lithium-ion batteries through a mixed culture of sulfur-oxidizing and iron-oxidizing bacteria. The dissolution of Co and Li from the spent lithium-ion battery depended exclusively on 
the non-contact mechanism, not on the contact mechanism. Bioacidic dissolution was applied as the bioleaching mechanism of $\mathrm{Li}$ in three bioleaching systems; Li displayed the maximum extraction efficiency in the S system due to its having the lowest $\mathrm{pH}$. However, the dissolution mechanisms of Co differed according to the energy materials. Acid dissolution was the sole mechanism for Co release in the S system, whilst a combined action of acid dissolution and $\mathrm{Fe}^{2+}$ mediated reduction accounted for Co release in the $\mathrm{S}+\mathrm{FeS}_{2}$ or $\mathrm{FeS}_{2}$ system.

Yoo et al. [51] treated the wastewater produced during a lithium primary battery recycling process using A. ferrooxidans, re-circulating the treated water in the process. The results of this investigation seem to suggest that wastewater treated by the bacteria can be reused in the recycling process as, during the treatment of the simulated wastewater, bacteria was found to grow in solutions with high metal concentrations such as $8000 \mathrm{~g} \mathrm{~m}^{-3}$ of $\mathrm{Cr}$ and $13,000 \mathrm{~g} \mathrm{~m}^{-3}$ of $\mathrm{Ni}$, but a Li concentration of $5000 \mathrm{~g} \mathrm{~m}^{-3}$ in a pure $9 \mathrm{~K}$ medium significantly suppresses the $\mathrm{Fe}^{2+}$ oxidation activity of the bacteria. In the case of a $90 \mathrm{vol} \%$ real wastewater solution, although a low Fe oxidation ratio is observed, the $\mathrm{pH}$ and Fe concentration decreased to 1.8 and $21,633 \mathrm{~g} \mathrm{~m}^{-3}$, respectively.

Due to the slow kinetics of bioleaching, commercial application of this method in metal extraction is relatively limited [49,50]. Thus different methods, such as improving bacterial cultivation, adhesion of metal-ions, and the addition of tensioactive agents, have been tested with the aim of improving bioleaching rates [5255]. Various authors [56-59], have shown that the rate of metal dissolution during the bioleaching process can be improved by adding catalytic ions to the solution.

Authors such as Hu et al. [60] and Carranza et al. [61], used metals such as $\mathrm{Ag}, \mathrm{Bi}, \mathrm{Ru}$ and $\mathrm{Hg}$, as catalysts. It is important, however, to use metal catalysts which are efficient while being cheap enough to enable application during the bioleaching process on an industrial scale.

Along these lines, Scott and Dyson [62], were the first to use $\mathrm{Cu}^{2+}$ as a catalyst in bioleaching. Dutrizac [63] investigated the effect of leaching by applying cupric chloride on sintered chalcopyrite in ferric chloride solution and found that the $\mathrm{CuCl}_{2}$ substantially speeds up the leaching rate. Chen et al. [64] found that copper ion was effective in the catalysis of metal sulfates.

Along these lines, Zeng et al. [65], developed a process of copper-catalyzed bioleaching to recycle cobalt in spent lithium-ion batteries (mainly $\mathrm{LiCoO}_{2}$ ). The authors studied the influence of copper ions on the bioleaching of $\mathrm{LiCoO}_{2}$ using Acidithiobacillus ferrooxidans (A.f). They proved that almost all of the cobalt (99.9\%) went into the solution after 6 days in the presence of $0.75 \mathrm{~g} / \mathrm{l}$ of copper ions, whilst only $43.1 \%$ of cobalt dissolution was achieved after 10 days without the use of copper ions.

\subsubsection{Solvent extraction}

Solvent extraction has been widely used for the recovery and separation of metals from the leach liquor, effluents, and the waste. Recovery of metal from waste $\mathrm{LiCoO}_{2}$ by leaching-solvent extraction is possible through different routes and using different extractants such as PC-88A [3], D2EHPA and PC-88A [66,67], and Cyanex 272 [35,68].

Swain et al. [69], developed a hydrometallurgical process (acid leaching, solvent extraction, scrubbing and stripping) for the recovery of a pure and marketable form of cobalt sulfate solution/ salt from the waste generated by the LiB industry. The results can be summed up as follows:

- The best condition for leaching cobalt from the waste $\mathrm{LiCoO}_{2}$ was found to be $2 \mathrm{M} \mathrm{H}_{2} \mathrm{SO}_{4}$ at a leaching temperature of $75^{\circ} \mathrm{C}$, pulp density of $100 \mathrm{~g} \mathrm{~L}^{-1}$, and $5 \mathrm{vol} \%$ of $\mathrm{H}_{2} \mathrm{O}_{2}$ for $30 \mathrm{~min}$. Under these conditions, the leaching efficiencies of cobalt and lithium were 93 and 94\%, respectively.

- The quantitative recovery of cobalt with a minimum lithium coextraction was achieved using a Cyanex 272 concentration of $1.5 \mathrm{M}$, an initial $\mathrm{pH}$ of 5 and an O/A ratio of 1.6 in a single stage. Subsequently, the rest of the cobalt was extracted at a Cyanex 272 concentration of $0.5 \mathrm{M}$, an initial $\mathrm{pH}$ of 5.35 and an $\mathrm{O} / \mathrm{A}$ ratio of 1 in a single stage.

Lupi et al. [70], carried out a hydrometallurgical process to recycle $\mathrm{Li}$-ion and $\mathrm{Li}$-polymer batteries containing both $\mathrm{LiCoO}_{2}$ and $\mathrm{Li}-\mathrm{CoxNi}_{(1-x)} \mathrm{O}_{2}$ as cathode materials. The operations involved in the process were: cathodic paste leaching, cobalt-nickel separation by solvent extraction with modified Cyanex 272 in kerosene, $\mathrm{Co}$ and Ni metal recovery by galvanostatic electrowinning and $\mathrm{Co}$ and $\mathrm{Ni}$ recovery by potentiostatic electrolysis carried out on partially depleted electrolytes. The results obtained were: Electrowinning of the metallic $\mathrm{Ni}$ is achieved at $250 \mathrm{~A} / \mathrm{m}^{2}, \mathrm{pH} \mathrm{3-3.2} \mathrm{and}$ $50{ }^{\circ} \mathrm{C}$, with $87 \%$ current efficiency and $2.96 \mathrm{kWh} / \mathrm{kg}$ specific energy consumption. Potentiostatic electrolysis produces a very poor $\mathrm{Ni}$ powder in about $1 \mathrm{~h}$ with current efficiency changing from $70 \%$ to $45 \%$ depending on $\mathrm{Ni}$ concentration in the electrolyte. Current efficiency of $96 \%$ and specific energy consumption of $2.8 \mathrm{kWh} / \mathrm{kg}$ were obtained for Co at $250 \mathrm{~A} / \mathrm{m}^{2}, \mathrm{pH} 4-4.2$ and $50^{\circ} \mathrm{C}$, by using a solution containing manganese and $\left(\mathrm{NH}_{4}\right)_{2} \mathrm{SO}_{4}$. The Co powder, produced in potentiostatic conditions $(-0.9 \mathrm{~V}$ vs. SCE, $\mathrm{pH} 4$, room temperature) appears particularly suitable for recycling Co as cobaltite in new batteries.

Nayl et al. [71], extracted and separated $\mathrm{Mn}(\mathrm{II}), \mathrm{Co}(\mathrm{II}), \mathrm{Ni}(\mathrm{II})$ and $\mathrm{Li}(\mathrm{I})$ from the leach liquor spent LIBs. Precipitates of $\mathrm{Mn}(\mathrm{II}), \mathrm{Co}(\mathrm{II})$, $\mathrm{Ni}(\mathrm{II})$ and $\mathrm{Li}(\mathrm{I})$ with purity $>99 \%$ could be obtained under the investigated conditions (20\% Acorga M5640 in kerosene with agitation for $5 \mathrm{~min}$ at $30^{\circ} \mathrm{C}$ at equal phase ratio of unity).

Chen et al. [72], proposed a combined hydrometallurgical process to recover metal values from the leaching liquor of spent LIBs by selective precipitation and solvent extraction. First, nickel was precipitated using dimethylglyoxime reagent after purification operation. Recycled dimethylglyoxime could be re-used as precipitant for nickel and revealed similar precipitation performance compared with fresh dimethylglyoxime. Then the separation of manganese and cobalt was conducted by solvent extraction method using cobalt loaded D2EHPA. Finally, cobalt and lithium were sequentially precipitated and recovered as $\mathrm{CoC}_{2} \mathrm{O}_{4} \cdot 2 \mathrm{H}_{2} \mathrm{O}$ and $\mathrm{Li}_{2} \mathrm{CO}_{3}$ using ammonium oxalate solution and saturated sodium carbonate solution, respectively. Recovery efficiencies could be attained as follows: $98.7 \%$ for $\mathrm{Ni}$; $97.1 \%$ for $\mathrm{Mn}, 98.2 \%$ for Co and 81.0\% for Li under optimized experimental conditions.

\subsubsection{Chemical precipitation}

The chemical precipitation method, applied during recovery and recycling of spent lithium-ion batteries, applies precipitation agents in order to precipitate precious metals present in the batteries, such as cobalt.

According to Ou et al. [73], the key to the success of this process lies in the selection of adequate chemical precipitation agents.

Contestabile et al. [21], developed a process under laboratory conditions for the treatment and recycling of spent lithium-ion batteries. The process involved the following stages: classification, trituration and sieving, selective separation of the active materials, lithium cobalt dissolution and cobalt hydroxide precipitation. The cobalt, dissolved in a chlorhydric solution, was recovered as cobalt hydroxide $\mathrm{Co}(\mathrm{OH})_{2}$ when equivalent volume of a $4 \mathrm{M} \mathrm{NaOH}$ solution was added.

Precipitation of cobalt hydroxide starts at pH 6 and is considered complete when $\mathrm{pH} 8$ is reached. Ideally, Co precipitation 


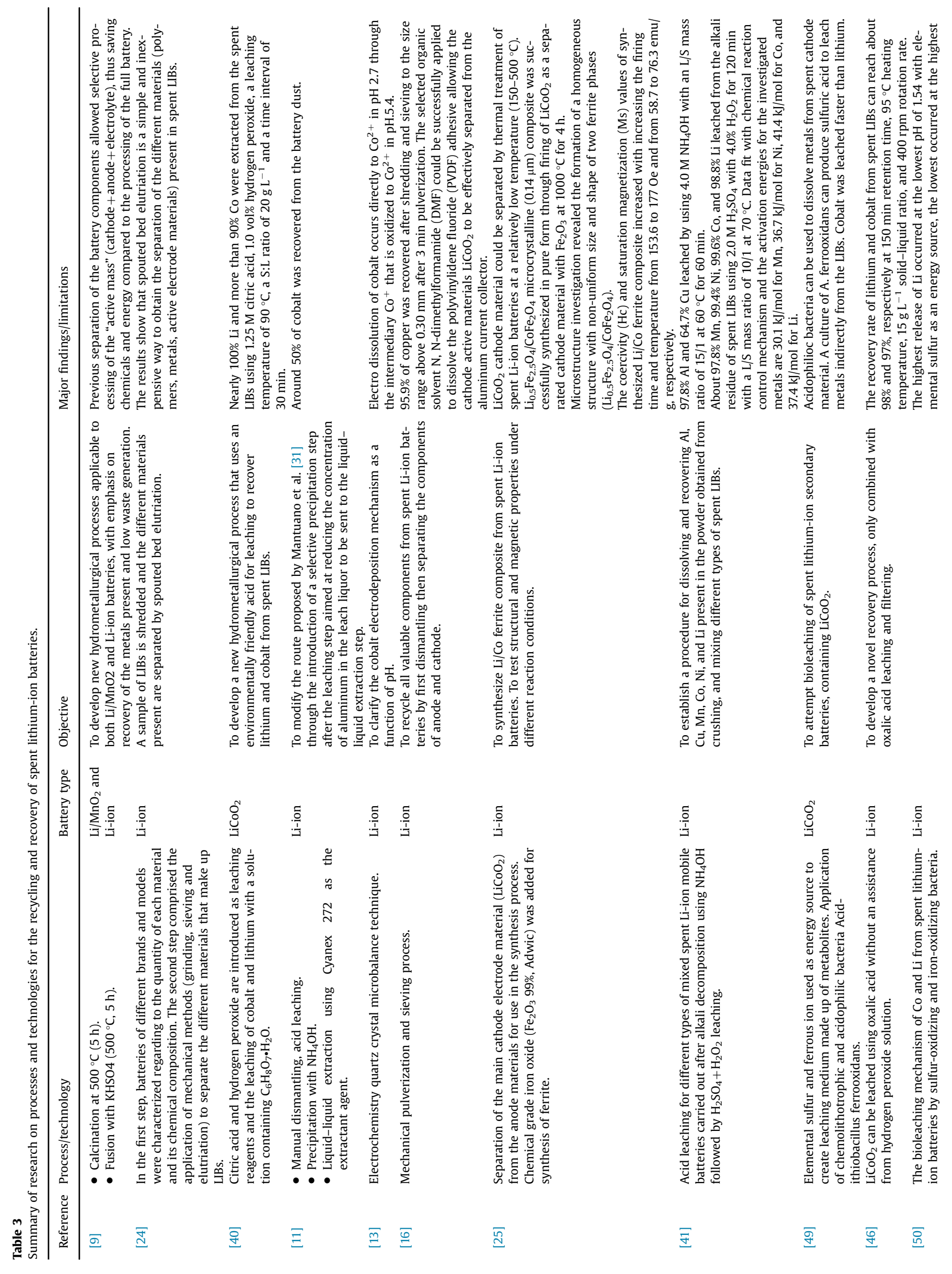




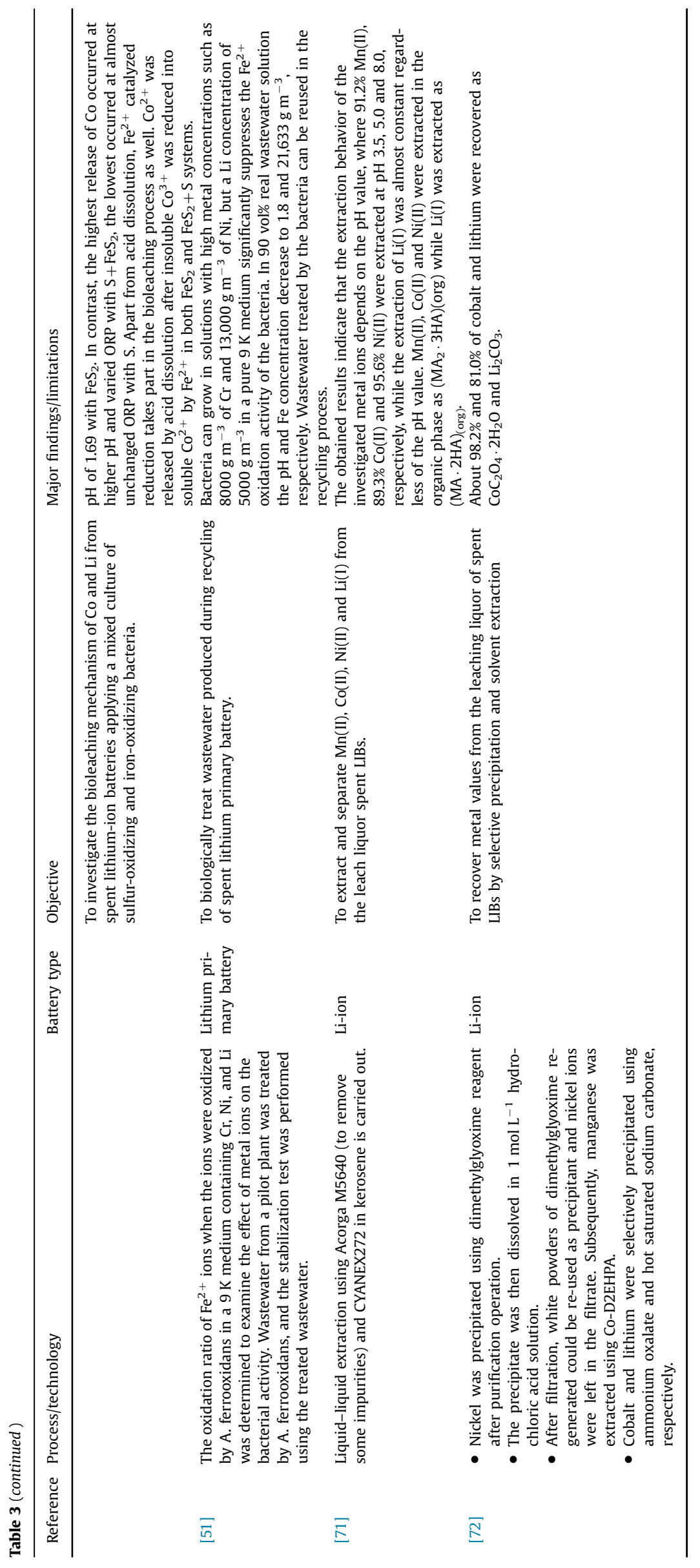


can be obtained using an ammoniac solution, a weak base, which forms a buffer solution at $\mathrm{pH} 9$. However, the ammoniac, when mixed with the cobalt, creates a stable complex, causing partial dissolution of the hydroxide, which prevents a quantitative recovery. Therefore $\mathrm{NaOH}$ is still the best option [12,23].

\subsubsection{Electrochemical process}

Myoung et al. [74] applied an electrochemical deposition and appropriate thermal treatment to prepare cobalt oxide from Co (III) of waste $\mathrm{LiCoO}_{2}$ cathodes. Under appropriate $\mathrm{pH}$ conditions, island-shaped cobalt hydroxide is precipitated on the titanium substrate and heat treatment of the cobalt hydroxide results in the formation of cobalt oxide.

Shen [75] investigated the recovery of cobalt from spent LiBs through sulfuric acid leaching and electrowinning. At $70^{\circ} \mathrm{C}$, with a sulfuric acid concentration of $10 \mathrm{~mol} \mathrm{~L}^{-1}$ and a retention time of one hour, almost $100 \%$ of the cobalt is dissolved. Hydrolyzed deposition purifies the leach liquor within the interval of $\mathrm{pH} 2.0$ 3.0 and $90^{\circ} \mathrm{C}$.

The cathode cobalt is produced through electrowinning in current density $235 \mathrm{~A} \mathrm{~m}^{-2}$. The quality of cathode cobalt is in accordance with China's 1 A\# cobalt standard GB6517-86. The net recovery of the cobalt is over $93 \%$.

Compared to other hydrometallurgical processes used to recycle the metals present in spent LiBs, electrolysis can obtain a very pure cobalt compound given that no other substances need be introduced, avoiding impurities [76]. However, this process tends to use large amounts of electricity.

Table 3 presents a summary of research on recycling and recovery of spent lithium-ion batteries.

\section{Conclusions}

\subsection{Major survey findings}

Spent lithium-ion batteries are classified as dangerous waste. If they are not properly treated, they will damage the environment and cause harm to animals and human health. Coupled with this, the fact that the batteries contain precious metals such as $\mathrm{Co}, \mathrm{Li}$ and $\mathrm{Mn}$ mean that, from an economical as well as an environmental point of view, the recycling and recuperation of these batteries is highly advantageous.

Through a thorough analysis of the research carried out in this area, it is clear that all processes and techniques applied in the recycling of lithium-ion batteries guarantee the recovery of the metals to a greater or lesser extent, whilst reducing the negative effect these batteries may have on the environment

Here is a summary of the main advantages and disadvantages of the processes analyzed:

- It is necessary to carry out a preliminary mechanical separation before heavy metals which make up lithium-ion batteries can be recovered. Mechanical separation also reduces the volume of waste and separates and enriches the components of the batteries.

- Furthermore, mechanical separation prior to leaching improves recovery efficiency of the target metals and makes purifying the leachates unnecessary.

- The spouted bed elutriation can be successfully employed as a viable and easy alternative to separate the materials that compose the spent LIBs.

- The advantages of thermal treatment are the simplicity and convenience of the operations. However the process has been linked to high emissions of dioxins, chloride compounds and mercury, making it necessary to install special equipment to purify the gases and smoke caused by combustion.

- The addition of $\mathrm{Al}_{2} \mathrm{O}_{3}$ is very effective for mechanochemical treatment enabling a high yield (more than $90 \%$ ) of Co as well as $\mathrm{Ni}$ and $\mathrm{Li}$ to be extracted from an amorphous scrap sample. For a successful dissolution process, the choice of the appropriate organic solvent, able to dissolve the polyvinylidene fluoride (PVDF) or the politetrafluoroetileno (PTFE) used as adhesives, is key. The downside to this process is the high cost of the solvent used (NMP) to dissolve the polyvinylidene fluoride (PVDF). This makes it inappropriate for use on an industrial scale. Due to its low cost, zero toxicity and environmental safety, DMSO at $60{ }^{\circ} \mathrm{C}$ for 85 min could be the most adequate solvent.

- Almost all the experimental results indicated that the leaching efficiency of Co is highest in hydrochloric acid.

- The main advantages of bioleaching processes are: their low cost, few industrial requirements, and that they are relatively environmentally friendly. Due to the slow kinetics of bioleaching, however, commercial application of this method in metal extraction is relatively limited.

- The extraction method using Cyanex 272 (bis-2, 4, 4trimethylpentyl phosphinic acid) is technically viable to separate base metals from NiCd, NiMH and Li-ion Batteries.

- Acorga M5640 can be effectively used as extractant for the extraction and separation of some ions such as $\mathrm{Fe}(\mathrm{III}), \mathrm{Cu}(\mathrm{II})$ and $\mathrm{Al}(\mathrm{III})$ which are found as impurities in the leach liquor of mixed types of spent LIBs. At a pH close to $1.0,99.2 \% \mathrm{Cu}$ was extracted; at $\mathrm{pH}$ 2.0-2.2 about $94 \% \mathrm{Fe}(\mathrm{III})$ and $95.6 \% \mathrm{Al}(\mathrm{III})$ were also extracted. The extraction of $\mathrm{Mn}(\mathrm{II}), \mathrm{Co}(\mathrm{II}), \mathrm{Ni}(\mathrm{II})$ and $\mathrm{Li}(\mathrm{I})$ was negligible.

- For successful chemical precipitation, the key lies in selecting adequate chemical precipitation agents. $\mathrm{NaOH}$ is still the best option.

- The electrolysis process can obtain a very pure cobalt compound given that no other substances need be introduced, avoiding impurities. However this process uses a lot of electricity.

\subsection{Future perspectives}

Currently, most of the research carried out in the area of recuperation and recycling of spent LiBs concentrates on recovering or recycling precious metals such as cobalt, nickel or lithium. The interest in recovering cobalt lies in the fact that it is a rare and precious metal. Nickel and lithium are expensive. There are however very few studies on the recovery of other metals such as graphite, the electrolyte in spent LIBs, and it is our belief that more research is needed in this area.

Technologies based on the use of microorganisms (bioleaching) are gaining prominence and maturity in the field of mineral processing. However, research into the application of this process in the recovery and recycling of used lithium batteries is few and far between.

The fact that the technology used in the manufacture of lithium-ion batteries is constantly changing makes subsequent changes to the research into recycling and recovery technologies necessary. This does not mean merely finding ways to recover the precious metals, but also to recover other materials which may harm the environment, in order to dispose of them appropriately.

\section{Acknowledgments}

This research was funded by research contract no. C-3869-00 between REGENARA S.L. and the Business Foundation of the 
University of Granada. We appreciate the collaboration and support of Miguel A. Lupión, CEO of REGENBAT, S.L.

\section{References}

[1] Zhang T, He Y, Wang F, Ge L, Zhu X, Li H. Chemical and process mineralogical characterizations of spent lithium-ion batteries: an approach by multianalytical techniques. Waste Manag 2014;34:1051-158.

[2] 〈http://batteryuniversity.com/learn/article/types_of_lithium_ion〉.

[3] Zhang P, Yokoyama T, Itabashi O, Suzuki TM, Inoue K. Hydrometallurgical process for recovery of metal values from spent lithium-ion secondary batteries. Hydrometallurgy 1998;47:259-71.

[4] Manthiram A. Materials challenges and opportunities of lithium ion batteries. J Phys Chem Lett 2011;2:176-84.

[5] Scrosati B, Garche J. Lithium batteries: status, prospects and future. J Power Sources 2010;195:2419-30.

[6] Nitta N, Wu F, Lee JT, Yushin G. Li-ion battery materials: present and future. Mater Today 2015;18(5):252-64.

[7] Etacheri V, Marom R, Elazari R, Salitra G, Aurbach D. Challenges in the development of advanced Li-ion batteries: a review. Energy Environ Sci 2011;4:3243-62.

[8] Hal A, Angelica VS. Toxicity of lithium to humans and the environment-a literature review. Ecotoxicol Environ Saf 2008;70:349-56.

[9] Jessica FP, Natalia GB, Julio CA. Recovery of valuable elements from spent Libatteries. J Hazard Mater 2008;150:843-9.

[10] Al-Thyabat S, Nakamura T, Shibata E, Iizuka A. Adaptation of minerals processing operations for lithium-ion (LiBs) and nickel metal hydride (NiMH) batteries recycling: critical review. Miner Eng 2013;45:4-17.

[11] Dorella G, Mansur MB. A study of the separation of cobalt from spent Li-ion battery residues. J Power Sources 2007;170:210-5.

[12] Xu J, Thomas HR, Francis RW, Lum KR, Wang J, Liang B. A review of processes and technologies for the recycling of lithium-ion secondary batteries. J Power Sources 2008; 177:512-27.

[13] Garcia EM, Santos JS, Pereira EC, Freitas MBJG. Electrodeposition of cobalt from spent Li-ion battery cathodes by the electrochemistry quartz crystal microbalance technique. J Power Sources 2008;185:549-53.

[14] Paulino JF, Busnardo NG, Afonso JC. Recovery of valuable elements from spent Li-batteries. J.Hazard Mater 2008;150:843-9.

[15] Kanamori T, Matsuda M, Miyake M. Recovery of rare metal compounds from nickel-metal hydride battery waste and their application to $\mathrm{CH}_{4}$ dry reforming catalyst. J Hazard Mater 2009;169:240-5.

[16] Zhou X, He W-Z, Li G-M, Zhang X-J, Huang J-W, Zhu S-G. Recycling of electrode materials from spent lithium-ion batteries, IEEE; 2010. p. 1-4. ISSN: 2151-7614.

[17] Dewulf J, Van Der Vorst G, Denturck K, Langenhovea H, Ghyootb W, Vandeputte K. Recycling rechargeable lithium-ion batteries: critical analysis of natural resource savings. Resour Conserv Recycl 2010;54:229-34.

[18] Khan KS, Kunz R, Kleijnen J, Antes G. Systematic reviews to support evidencebased medicine: how to review and apply findings of health care research. London: Royal Society of Medicine Press; 2003.

[19] Pullin AS, Stewart GB. Guidelines for systematic review in conservation and environmental management. Conserv Biol 2006;20:1647-56.

[20] Tenório JAS, Oliveira DC, Chaves AP. Carbon-zinc batteries treatment by ore processing methods. In: Proceedings of the global symposium on recycling waste treatment and clean technology (REWAS'99), vol. II; 1999; p. 1153-60.

[21] Contestabile M, Panero S, Scrosati B. A laboratory-scale lithium battery recycling process. J Power Sources 1999;83(1-2):75-8.

[22] Bernardes AM, Espinosa DCR, Tenório JAS. Recycling of batteries: a review of current processes and technologies. J Power Sources 2004;130:291-8.

[23] Shin SM, Kim NH, Sohn JS, Yang DH, Kim YH. Development of a metal recovery process from Li-ion battery wastes. Hydrometallurgy 2005;79:172-81.

[24] Bertuol DA, Toniasso C, Jimenez BM, Meili L, Dotto GL, Tanabe EH, Aguiar ML. Application of spouted bed elutriation in the recycling of lithium ion batteries. J Power Sources 2015;275:627-32.

[25] Bahgat M, Farghaly FE, Abdel Basir SM, Fouad OA. Synthesis, characterization and magnetic properties of microcrystalline lithium cobalt ferrite from spent lithium-ion batteries. J Mater Process Technol 2007;183:117-21.

[26] Zhang Q, Lu J, Saito F, Nagata C, Ito Y. Room temperature acid extraction of Co from $\mathrm{LiCO}_{0.2} \mathrm{Ni}_{0.8} \mathrm{O}_{2}$ scrap by a mechanochemical treatment. Adv Powder Technol 2000;11:353-60.

[27] Tanaka Y, Zhang Q Saito F. Synthesis of spinel $\mathrm{Li}_{4} \mathrm{Mn}_{5} \mathrm{O}_{12}$ with an aid of mechanochemical treatment. Powder Technol 2003;132:74-80.

[28] Saeki S, Lee J, Zhang Q, Saito F. Co-grinding $\mathrm{LiCOO}_{2}$ with PVC and water leaching of metal chlorides formed in ground product. Int J Miner Process 2004;74S:S373-8.

[29] Zhang Q, Saito F, Shimme K, Masuda S. Dechlorination of PVC by a mechanochemical treatment under atmospheric condition. J Soc Powder Technol 1999;36:468-73.

[30] Saeki S, Kano J, Saito F, Shimme K, Masuda S, Inoue T. Effect of additives on dechlorination of PVC by mechanochemical treatment. J Mater Cycles Waste Manag 2001;3:20-3.

[31] Zhang Q Saito F. Non-thermal process for extracting rare earth from Bastnaesite by means of mechanochemical treatment. Hydrometallugy 1998;47:231-41.

[32] Lee J, Zhang Q, Saito F. Room temperature extraction of Co and Li from ground lithium-ion secondary battery scrap. Shigen Sozai 2000;116:919-22.
[33] Bankole OE. Battery recycling technologies: recycling waste lithium-ion batteries with the impact on the environment in-view. J Environ Ecol 2013;4(1):14-28.

[34] Bankole OE, Lei L. Silicon exchange effects of glassware on the recovery of LiPF6: alternative route to preparation of $\mathrm{Li}_{2} \mathrm{SiF}_{6}$. J Solid Waste Technol Manag 2014:39(4):254.

[35] Mantuano DP, Dorella G, Elias RCA, Mansur MB. Analysis of a hydrometallurgical route to recover base metals from spent rechargeable batteries by liquid-liquid extraction with Cyanex 272. J Power Sources 2006;159(2):1510-8.

[36] Castillo S, Ansart F, Laberty-Robert C, Portal J. Advances in the recovering of spent lithium battery compounds. J Power Sources 2002;112(1):247-54.

[37] Lee CK, Rhee K-I. Reductive leaching of cathodic active materials from lithiumion battery wastes. Hydrometallurgy 2003;68(1-3):5-10.

[38] Lee CK, Rhee K-I. Preparation of $\mathrm{LiCoO}_{2}$ from spent lithium-ion batteries J Power Sources 2002;109(1):17-21.

[39] Kim D-S, Sohn J-S, Lee C-K, Lee J-H, Han K-S, Lee Y-I. Simultaneous separation and renovation of lithium cobalt oxide from the cathode of spent lithium-ion rechargeable batteries. J Power Sources 2004;132(1-2):145-9.

[40] Li L, Ge J, Wu F, Chen R, Chen S, Wu B. Recovery of cobalt and lithium from spent lithium-ion batteries using organic citric acid as leachant. J Hazard Mater 2010;176:288-93.

[41] Nayl AA, Elkhashab RA, Badawy SM, El-Khateeb MA. Acid leaching of mixed spent Li-ion batteries. Arabian J Chem 2014 xxx:xxx-xxx [article in press].

[42] Zou H, Gratz E, Apelian D, Wang Y. A novel method to recycle mixed cathode materials for lithium ion batteries. Green Chem 2013;15:1183-91.

[43] Li L, Zhai L, Zhang X, Lu J, Chen R, Wu F, Amine K. Recovery of valuable metals from spent lithium-ion batteries by ultrasonic-assisted leaching process. J Power Sources 2014;262:380-5.

[44] Zhang X, Xie Y, Lin X, Li H, Cao H. An overview on the processes and technologies for recycling cathodic active materials from spent lithium-ion batteries. J Mater Cycles Waste Manag 2013:15:420-30.

[45] Joulié M, Laucournet R, Billy E. Hydrometallurgical process for the recovery of high value metals from spent lithium nickel cobalt aluminum oxide based lithium-ion batteries. J Power Sources 2014;247:551-5.

[46] Zeng X, Li J, Shen B. Novel approach to recover cobalt and lithium from spent lithium-ion battery using oxalic acid. J Hazard Mater 2015;295:112-8.

[47] Brandl H, Faramarzi MA. Microbe-metal-interactions for the biotechnological treatment of metal-containing solid waste. China Part 2006;4(2):93-7.

[48] Rohwerder T, Gehrke T, Kinzler K, Sand W. Bioleaching review part A: progress in bioleaching: fundamentals and mechanisms of bacterial metal sulfide oxidation. Appl Microbiol Biotechnol 2003;63:239-48.

[49] Mishra D, Kim D, Ralph DE, Ahn J, Rhee Y. Bioleaching of metals from spent lithium-ion secondary batteries using Acidithiobacillus ferrooxidans. Waste Manag 2008;28:333-8.

[50] Xin B, Zhang D, Zhang X, Xia Y, Wu F, Chen S, Li L. Bioleaching mechanism of Co and Li from spent lithium-ion battery by the mixed culture of acidophilic sulfuroxidizing and iron-oxidizing bacteria. Bioresour Technol 2009;100:6163-9.

[51] Yoo K, Shin S, Yang D, Sohn J. Biological treatment of wastewater produced during recycling of spent lithium primary battery. Miner Eng 2010;23:219-24.

[52] Ballester A, Gonzalez F, Blazquez ML. The use of catalytic ions in bioleaching. Hydrometallurgy 1992;29:145-60.

[53] Escudero ME, Gonzalez F, Blazquez ML. The catalytic effect of some cations on the biological leaching of a Spanish complex sulphide. Hydrometallurgy 1993;34:151-69.

[54] Mier JL, Ballester A, Blazquez ML. Influence of metallic ions in the bioleaching of chalcopyrite by sulfolobus BC: experiments using pneumatically stirred reactors and massive samples. Miner Eng 1995;8:949-65.

[55] Wang M, Zhang Y, Deng T. Kinetic modeling for the bacterial leaching of chalcopyrite catalyzed by silver ions. Miner Eng 2004:17:943-7.

[56] Muñoz JA, Dreisinger DB, Cooper WC. Silver-catalyzed bioleaching of lowgrade copper ores. Part I. Shake flasks tests. Hydrometallurgy 2007;88:3-18.

[57] Muñoz JA, Dreisinger DB, Cooper WC. Silver-catalyzed bioleaching of lowgrade copper ores. Part II. Stirred tank tests. Hydrometallurgy 2007;88:19-34.

[58] Muñoz JA, Dreisinger DB, Cooper WC. Silver catalyzed bioleaching of lowgrade copper ores. Part III. Column reactors. Hydrometallurgy 2007:88:35-51.

[59] Guo P, Zhang G, Cao J, Li Y, Fang Z, Yang C. Catalytic effect of $\mathrm{Ag}^{+}$and $\mathrm{Cu}^{2+}$ on leaching realgar $\left(\mathrm{As}_{2} \mathrm{~S}_{2}\right)$. Hydrometallurgy 2011;106:99-103.

[60] Hu YH, Qiu GZ, Wang J. The effect of silver-bearing catalysts on bioleaching of chalcopyrite. Hydrometallurgy 2002;64:81-8.

[61] Carranza F, Palencia I, Romero R. Silver catalyzed IBES process: application to a Spanish copper-zinc sulphide concentrate. Hydrometallurgy 1997:44:29-42.

[62] Scott TR, Dyson NF. The catalyzed oxidation of zinc sulfide under acid pressure leaching conditions. Trans Metall Soc AIME 1968;242:1815-21.

[63] Dutrizac JE. The kinetics of dissolution of chalcopyrite in ferric ion media Metall Trans B 1978;9:431-9.

[64] Chen S, Qin WQ, Qiu GZ. Effect of $\mathrm{Cu}^{2+}$ ions on bioleaching of marmatite Trans Nonferr Met Soc 2008;18:1518-22.

[65] Zeng G, Deng X, Luo S, Luo X, Zou J. A copper-catalyzed bioleaching process for enhancement of cobalt dissolution from spent lithium-ion batteries. J Hazard Mater 2012;199- 200:164-9.

[66] Wu F. Recovery of cobalt and lithium from spent lithium-ion secondary batteries. Zhongguo Youse Jinshu Xuebao 2004;14(4):697-701 [in Chinese].

[67] Zhang P, Yokoyama T, Itabashi O, Wakui Y, Suzuki TM, Inoue K. Hydrometallurgical process for recovery of metal values from spent nickel-metal hydride secondary batteries. Hydrometallurgy 1998;50:61-75. 
[68] Nan J, Han D, Zuo X. Recovery of metal values from spent lithium-ion batteries with chemical deposition and solvent extraction. J Power Sources $2005 ; 152: 278-84$

[69] Swain B, Jeong J, Lee J-C, Lee G-H, Sohn J-S. Hydrometallurgical process for recovery of cobalt from waste cathodic active material generated during manufacturing of lithium-ion batteries. J Power Sources 2007;167:536-44.

[70] Lupi C, Pasquali M, Dell'Era A. Nickel and cobalt recycling from lithium-ion batteries by electrochemical processes. Waste Manag 2005;25:215-20.

[71] Nayl AA, Hamed MM, Rizk SE. Selective extraction and separation of metal values from leach liquor of mixed spent Li-ion batteries. J Taiwan Inst Chem Eng 2015;55:119-25.
[72] Chen X, Chen Y, Zhou T, Liu D, Hu H, Fan S. Hydrometallurgical recovery of metal values from sulfuric acid leaching liquor of spent lithium-ion batteries. Waste Manag 2015;38:349-56.

[73] Ou X, Sun X, Zhao Q, Fan F. Progress in recovery technology of waste lithiumion battery. J. Inorg Chem Ind 2005;37(9):11-4 [in Chinese].

[74] Myoung J, Jung Y, Lee J, Tak Y. Cobalt oxide preparation from waste $\mathrm{LiCoO}_{2}$ by electrochemical-hydrothermal method. J Power Sources 2002;112:639-42.

[75] Shen Y. Chin J Nonferr Metals 2002;54:69-71 [in Chinese].

[76] Sun X, Wei J, Wang X, Ye M, Yan J, Gao X. Chin J Power Sources 2004;28 (12):794-7 [in Chinese]. 